\title{
Aerial survey abundance estimates of the loggerhead sea turtle Caretta caretta in the Pelagos Sanctuary, northwestern Mediterranean Sea
}

\author{
Giancarlo Lauriano $^{1, *}$, Simone Panigada ${ }^{2,1}$, Paolo Casale $^{3}$, Nino Pierantonio ${ }^{1,2}$, \\ Greg P. Donovan ${ }^{4}$ \\ ${ }^{1}$ Institute for Environmental Protection and Research (ISPRA), Via di Casalotti 300, 00166 Roma, Italy \\ ${ }^{2}$ Tethys Research Institute, Viale G. B. Gadio 2, 20121 Milano, Italy \\ ${ }^{3}$ Department of Biology and Biotechnologies 'Charles Darwin', University of Rome 'La Sapienza', 00185 Roma, Italy \\ ${ }^{4}$ The International Whaling Commission, The Red House, 135 Station Road, Impington, Cambridge, CB24 9NP, UK
}

\begin{abstract}
Aerial line transect surveys, totalling $16590 \mathrm{~km}$, were performed in winter and summer 2009 in the Pelagos Sanctuary, NW Mediterranean. A total of 207 loggerhead sea turtles were sighted, with only 9 sightings during the winter. In this season average raw 'surface' density (i.e. animals at or near the surface) was 0.002 turtles $\mathrm{km}^{-2}$, and on the basis of line-transect analysis, we estimated 237 specimens $(\mathrm{CV}=34.33 \% ; 95 \% \mathrm{CI}=122-461)$. The summer estimate resulted in 4083 animals at surface $(\mathrm{CV}=14.59 \% ; 95 \% \mathrm{CI}=3061-5466)$ in the study area, with a density of $0.046 \mathrm{~km}^{-2}$. Results indicated strong seasonal differences and lower densities than those found in comparable surveys in Spanish Mediterranean waters. Nevertheless, the ecological and oceanographic features of the Pelagos Sanctuary, established primarily for the protection of marine mammals, render it an important area also for Mediterranean loggerhead sea turtles. The potential for human-induced mortalities of turtles summering in the Pelagos Sanctuary is high. In this context, it is vital to obtain reliable estimates of absolute and relative abundance over time, monitor the status of loggerhead sea turtles and inform the development of effective conservation actions. This study illustrates the ability of aerial surveys to provide such data in this area.
\end{abstract}

KEY WORDS: Loggerhead sea turtle - Caretta caretta - Pelagos Sanctuary - Aerial survey · Abundance $\cdot$ Seasonal distribution $\cdot$ Distance sampling

\section{INTRODUCTION}

The loggerhead sea turtle Caretta caretta is the most common sea turtle species in the Mediterranean Sea (Margaritoulis et al. 2003) and is listed as Endangered in the IUCN Red List of Threatened Species (www.iucnredlist.org). The Mediterranean Basin hosts 2 Regional Management Units (RMU) of loggerhead sea turtles: the Mediterranean and the northwest Atlantic (Wallace et al. 2010). The most recent status review (Conant et al. 2009) concluded that although there were insufficient data to reliably assess the status of the Mediterranean discrete population segments of C. caretta, the potential for future decline was high. Notwithstanding the uncertainties in the available data, bycatch is considered to be the main anthropogenic threat (Tomás et al. 2008, Casale \& Margaritoulis 2010, Casale et al. 2010). In addition, there is increasing evidence of the importance of vessel strikes as a source of mortality (Hazel et al. 2007, Panigada et al. 2008, Casale et al. 2010); other potential threats include the degradation of nesting habitats due to coastal development (Casale \& Margaritoulis 2010).

Loggerhead sea turtles prey upon several epipelagic and benthic animal taxa in a variety of habitats during their lifetime. Apart from young animals that have limited diving capacity, loggerhead sea turtles can shift 
between oceanic and neritic zones and between pelagic and benthic prey, although their foraging strategies are not yet fully understood (Hawkes et al. 2006, McClellan \& Read 2007, Casale et al. 2008a, Frick et al. 2009, Mansfield et al. 2009, Reich et al. 2010). In the oceanic zone, where the sea bottom is inaccessible to them, loggerhead sea turtles feed upon epipelagic animals, often in aggregations with floating Sargassum (Bjorndal 1997, Bolten 2003), and can disperse over wide areas and even entire oceans (Bowen et al. 1995, Bolten et al. 1998). In the neritic zone, they have access to the entire water column and thus can also feed on benthic animals (Bjorndal 1997).

In the Mediterranean Sea, the presence of both neritic and oceanic areas within short distances enhances the intrinsic opportunistic foraging strategy of the species (Casale et al. 2008a). Loggerhead sea turtles originating from the Atlantic enter the Mediterranean and can be found in the western and the eastern part of the basin, at least as far as the central Mediterranean (Laurent et al. 1998, Carreras et al. 2006, Casale et al. 2008b).

Foraging areas can be found all over the basin (Margaritoulis et al. 2003, Casale \& Margaritoulis 2010), whereas reproductive areas are largely restricted to the eastern Mediterranean Sea, in particular Greece, Turkey, Cyprus and Libya, with less important areas in Egypt, Israel, Italy, Syria, and Tunisia (Conant et al. 2009, Casale \& Margaritoulis 2010). Mark-recapture and satellite tracking studies have revealed wide-ranging movements between reproductive and foraging areas, as well as amongst different foraging grounds (Margaritoulis et al. 2003, Broderick et al. 2007, Casale et al. 2007b, Revelles et al. 2007, Zbinden et al. 2008). Evidence of long-term neritic and oceanic foraging areas for adults and juveniles have been provided by mark-recapture programmes (Casale et al. 2007b). Telemetry and flipper tagging data also reveal consistent migrations of females to and from nesting areas (Margaritoulis et al. 2003, Broderick et al. 2007, Zbinden et al. 2008).

However, current knowledge of loggerhead sea turtle distribution and abundance in the Mediterranean Sea is still primarily qualitative, and is largely based on opportunistic data (e.g. bycatch reports) restricted to few areas (Tomás et al. 2008, Casale et al. 2010, Casale \& Margaritoulis 2010). Relative abundance can be inferred by standardized catch rates from bycatch studies (Casale 2011); however, these data are collected opportunistically and are potentially biased.

The absence of key data, and the uncertainties in the current knowledge of distribution and abundance in Mediterranean waters, emphasises the need for reliable and quantifiable information. Such data are needed to inform a full assessment of threats at population level, an improved understanding of the possible effects of climate change (Hawkes et al. 2009, Witt et al. 2010), and the development of adequate, targeted mitigating actions (e.g. BraunMcNeill et al. 2008, Howell et al. 2008).

Obtaining reliable measures of absolute and relative abundance is also considered to be of high priority for sea turtle research worldwide (Hamann et al. 2010). It is thought that 'distance sampling' (Buckland et al. 2001) is the preferred method to estimate turtle abundance and density (Shoop \& Kenney 1992, Epperly et al. 1995, Braun \& Epperly 1996, Davis \& Fargion 1996, Preen et al. 1997, Davis et al. 2000, Gómez de Segura et al. 2003, 2006). However, only a few studies have actually applied this approach for sea turtles, either through boat-based (Eguchi et al. 2007) or aerial surveys (Witt et al. 2009). The only reliable estimate of sea turtle abundance in the Mediterranean, prior to the present study, was obtained from an aerial survey undertaken in Spanish Mediterranean waters along the Valencia coast in 2001-2003 (Gómez de Segura et al. 2006).

One of the areas where loggerhead sea turtle occurrence remains poorly described is the northernmost part of the western Mediterranean Basin; the only available information comes from fishery surveys (Di Natale et al. 1995, Orsi Relini et al. 1999). However, from a stock structure perspective, the picture is somewhat clearer and the available genetic data suggest that the Liguro-Provençal current is frequented mainly by turtles of Mediterranean origin, with little contribution from the North Atlantic (Carreras et al. 2006). Hence, assessing sea turtle abundance (and ultimately trends) in this area would be of great benefit for the conservation of the Mediterranean Sea loggerhead sea turtle population.

The study area lies within the Pelagos Sanctuary for Mediterranean Marine Mammals. This was established by Italy, France and the Monaco Principality in 2001 and represents the world's first high seas marine protected area (Hoyt 2005). It encompasses almost $90000 \mathrm{~km}^{2}$ of both pelagic and coastal waters between the Italian, Monegasque and French coasts of the Ligurian Sea and the north of Sardinia Island. The area is recognized for its high productivity and notably high cetacean concentrations, especially in summer (Notarbartolo di Sciara et al. 2008). In order to provide information for the management of the Pelagos Sanctuary, the Italian Ministry of the Environment funded a series of research programmes aimed at estimating cetacean abundance throughout the year in the seas around 
Italy. In this context, 2 aerial distance sampling surveys (winter and summer) were carried out in 2009 (Lauriano \& Panigada 2010, Panigada et al. 2011). Although the surveys were targeted at cetaceans, data were also collected for other species, including the loggerhead sea turtle. A number of authors have suggested that aerial surveys provide a reliable approach to estimating the density and abundance of turtles (Shoop \& Kenney 1992, Epperly et al. 1995, Braun \& Epperly 1996, Davis \& Fargion 1996, Preen et al. 1997, Davis et al. 2000, Gómez de Segura et al. 2003, 2006).

This study presents, for the first time, seasonal abundance estimates for the loggerhead sea turtle in the Pelagos Sanctuary and quantitative information on distribution within the area, at least at the time of the aerial surveys. We compare our results with a similar study conducted in Spanish Mediterranean waters and demonstrate the utility of conducting aerial surveys to assess sea turtle abundance. The results contribute to the conservation of the species, providing information on the potential value of the Pelagos Sanctuary for the conservation of large marine vertebrates other than cetaceans.

\section{MATERIALS AND METHODS}

\section{Study area}

The area surveyed was the Pelagos Sanctuary (Fig. 1), a semi-basin with a widely extended bathyal plain at approximately $2500 \mathrm{~m}$ depth, associated with

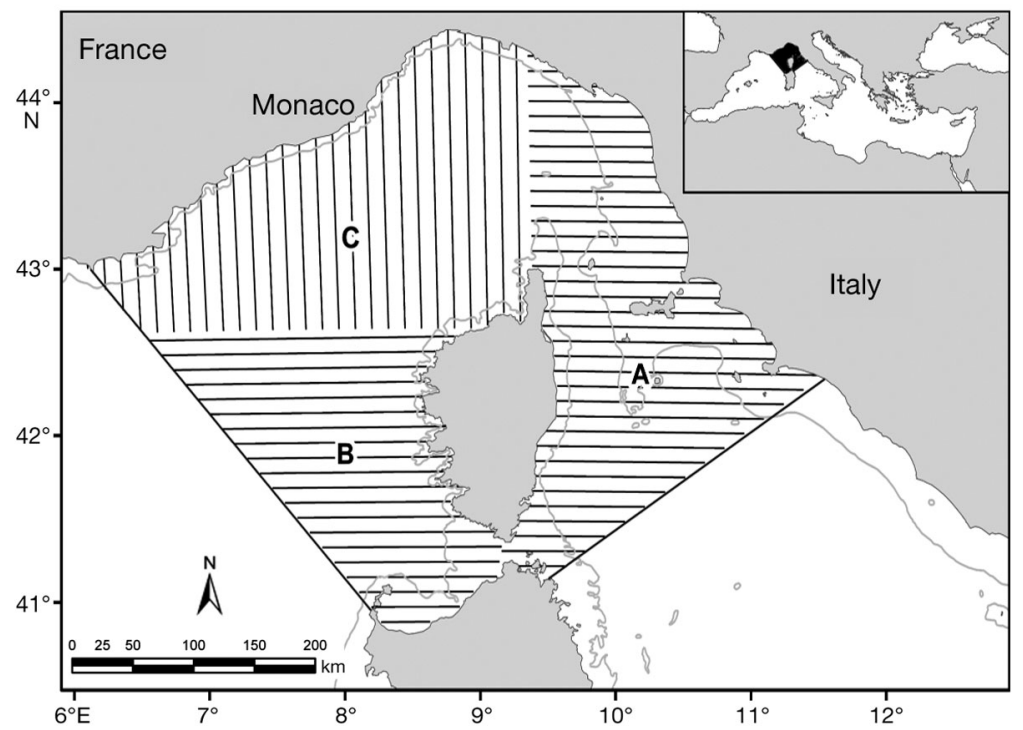

Fig. 1. Study area (Pelagos Sanctuary), showing the 82 transects (lines) in 3 sub-regions (A, B and C) used to estimate loggerhead sea turtle abundance and density in the present study a narrow continental shelf in the west $(\sim 5 \mathrm{~km})$ and a more extended $(>10 \mathrm{~km})$ shelf in the east. A highly dynamic frontal system, caused by the interaction of oceanographic, climatic and geomorphologic factors, leads to a biologically productive area. It represents one of the most highly variable ecosystems in the Mediterranean Basin (Estrada 1996, Salat 1996, Arnau et al. 2004, Notarbartolo di Sciara et al. 2008). Its importance for cetaceans was first described in the early 1990s (Notarbartolo di Sciara et al. 1993, Forcada et al. 1995). In 2001, under a high seas agreement established under the Barcelona Convention, the Pelagos Sanctuary was added to the list of Specially Protected Areas of Mediterranean Importance, which, at least officially, conferred protection by all signatory Mediterranean countries in both national waters and in the high seas (Hoyt 2005, Notarbartolo di Sciara et al. 2008).

\section{Survey design}

This paper reports on 2 aerial surveys. The survey design and methods (and subsequent analyses) were in accordance with line-transect distance sampling methodology (Buckland et al. 2001). The platform used was a 2 engine high-wing aircraft (Partenavia P68) equipped with bubble windows (to allow direct observation of the trackline below the plane) flying at a constant altitude of 750 feet $(229 \mathrm{~m})$ with a ground speed of approximately 100 knots $\left(185 \mathrm{~km} \mathrm{~h}^{-1}\right)$. The survey height was designed to be optimal for the major target species: the fin whale Balaenoptera physalus and the striped dolphin Stenella coeruleoalba (Panigada et al. 2011). Three experienced researchers were on board: 2 were seated in the rear seats searching for animals through the bubble windows and the third observer was in the co-pilot seat, recording the data (see below) directly onto a laptop. The aircraft flew along 82 parallel transects, equally spaced at $10 \mathrm{~km}$, designed using the software Distance 5.0 (1www.ruwpa.st-and.ac.uk/distance/; Thomas et al. 2009) to provide equal coverage probability (Fig. 1). The total planned survey distance was $8852.56 \mathrm{~km}$. The area was subdivided in 3 sub-regions, primarily based on bathymetry: (A) east (30907 km²), (B) southwest $\left(23208 \mathrm{~km}^{2}\right)$ and (C) northwest (34 $\left.153 \mathrm{~km}^{2}\right)$.

At each sighting, data collected included GPS position (latitude, longitude), group size, declination angle when the sighting 
was estimated to be abeam and observer. Primary search effort data (distance flown in acceptable conditions) and altitude were recorded directly from the GPS. Data were recorded directly onto a laptop with data logging programs. Acceptable conditions were defined as Beaufort state 3 or less. Additional relevant information such as sea state, glare, cloud cover and subjective sighting condition (the observers' view as to their ability to see an animal at the surface if present on a 3-point scale) was recorded at the beginning of each transect and/or whenever changes occurred. Declination angle to the sighting was measured with Suunto clinometers that,

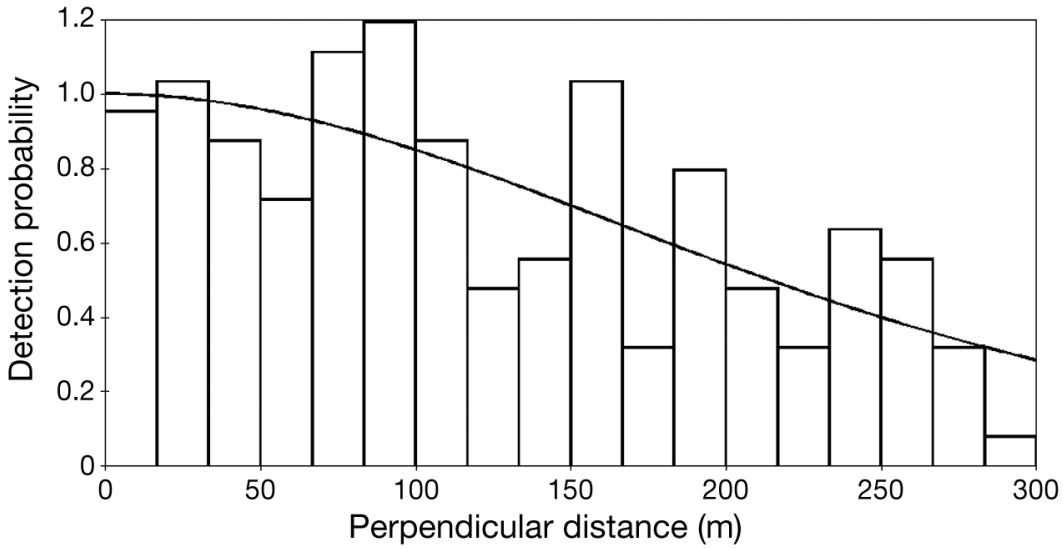

Fig. 2. Pooled detection function (winter and summer sightings), using the $300 \mathrm{~m}$ truncation. Bars represent the detection probability and the curve shows the detection probability trend according with the distance from the line (transect) together with the plane altitude, allowed the perpendicular distance from the track line to the sighting to be measured, according to the formula $X=$ $h \times \tan (90-\alpha)$, where $h$ is the plane altitude and $\alpha$ is the declination angle.

\section{Data analysis}

Distance analyses of the sightings data were performed using the dedicated software Distance 6.0; multiple covariate distance sampling (MCDS) methods were applied (Buckland et al. 2001, Thomas et al. 2007, 2010). In MCDS, additional explanatory variables $(z)$ are considered along with perpendicular distance in the estimation of the detection function and hence the effective strip width. The potential covariates considered were observer, Beaufort sea state and glare (all as factor variables with 3 levels each). The best model fit, selected using the minimum Akaike's information criterion (AIC) value (Akaike 1974, Buckland et al. 2001), indicated that the variable 'observer' should be included in the detection function (Table 1, Fig. 2).

Table 1. Akaike's information criterion (AIC) values for the multiple covariate distance sampling. All covariates are fitted as factors with 3 levels each

\begin{tabular}{|lccc|}
\hline Model & AIC & $\begin{array}{c}\text { Delta } \\
\text { AIC }\end{array}$ & $\begin{array}{c}\text { No. } \\
\text { parameters }\end{array}$ \\
\hline Observer & 1850.18 & 0 & 3 \\
Sea state & 1854.09 & 3.91 & 4 \\
Glare & 1853.22 & 3.04 & 4 \\
Sea state + Glare & 1856.75 & 6.57 & 7 \\
Sea state + Observer & 1855.21 & 5.04 & 6 \\
Observer + Glare & 1854.04 & 3.86 & 6 \\
\hline
\end{tabular}

Abundance was estimated using a Horvitz-Thompson-like estimator formula, according to Marques et al. (2007):

$$
\widehat{N}=\frac{A}{2 W L} \sum_{i=1}^{\mathrm{n}} \frac{1}{\widehat{P}_{a}\left(z_{i}\right)}
$$

where $A$ is the area of the study area, $\mathrm{n}$ is the number of sightings, $L$ is the total search effort (total transect length), $w$ is the half strip width, $2 w L=a$ is the covered area, $\hat{P}_{a}$ is the estimated probability of detecting the $i$ th object within the covered area $a$, and $z$ is the covariate. Variance of $\mathrm{n}$ was empirically estimated from stratified samples with overlapping sub-regions (Estimator O2) (Fewster et al. 2009).

A simple power analysis was performed to explore the $80 \%$ power of the survey results to detect changes in abundance in a monitoring programme such as the one presented; based on the results from the summer survey, a coefficient of variation (CV) of $15 \%$ was chosen using TRENDS software (Gerrodette 1993). The following parameters were also selected: significance level $\alpha=0.05$; 1 -tailed test; linear model of rate of change; $\mathrm{CV}$ proportional to the square root of the abundance estimate; standard normal distribution.

\section{RESULTS}

The first aerial survey was conducted in winter 2009 between 11 to 31 January and 18 to 22 February (the interval due to poor weather conditions and essential aircraft maintenance). The second survey, with identical sub-areas, track-lines and methods as the first, was undertaken in summer 2009 between 21 July and 2 August. 

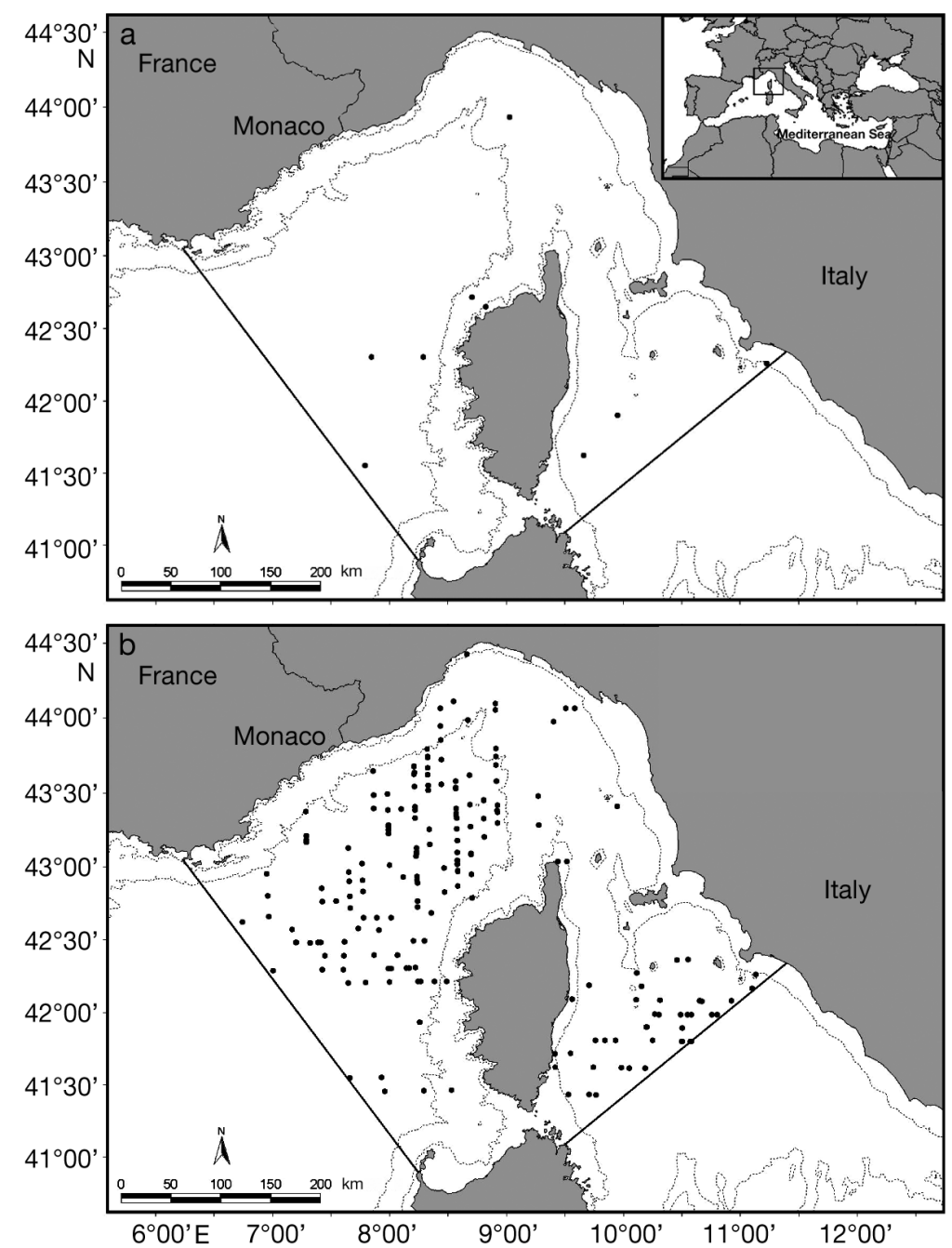

Fig. 3. Loggerhead sea turtle sightings $(\bullet)$ in the study area in (a) winter and (b) summer

In the winter survey, a distance of $8144 \mathrm{~km}(92 \%$ of the total projected survey distance) was flown, but only 9 turtle sightings were recorded (Fig. 3a); it is clear that the low number of sightings reflected low presence.

During the summer, even better coverage $(97 \%)$ was obtained and 198 loggerhead sea turtles were sighted (Fig. 3b). However, 27 (13.6\%) of these sightings lacked the declination angle (6 ind. in subregion A, 9 in B and 12 in C). Accordingly, 165 sightings were carried forward to density/abundance analyses. All sightings of sea turtles were of single animals. Winter and summer sightings were pooled to fit a detection function, which was applied to obtain the winter and summer estimates.

To fit the detection function, the perpendicular distance to sightings was truncated at $300 \mathrm{~m}$, resulting in 164 (9 in winter and 155 in summer) of the potential
174 (9 in winter, 165 in summer) sightings, which were incorporated in the final analyses. Two different functions were considered: half normal and hazard rate, together with cosine and simple polynomial series expansion. Based on the minimum AIC value, the best model was the half normal with cosine adjustment terms.

The effective strip width was $201.98 \mathrm{~m}$ $(\mathrm{CV}=4.74 \% ; 95 \% \mathrm{CI}=183.95$ to 221.78$)$, the probability of observing an object in a defined area was $0.67(\mathrm{CV}=4.74 \%)$ and the probability density function evaluated at zero distance was $0.0049(\mathrm{CV}=4.74 \%)$.

The overall mean winter surface density (not corrected for availability bias [animals under the water that therefore could not be seen by the observers] or perception bias [animals at the surface that were missed by the observers]) was 0.0026 turtles $\mathrm{km}^{-2}$ with a total surface estimate of 237 animals $(\mathrm{CV}=34.33 \%$; $95 \% \mathrm{CI}=122$ to 461) (Table 3). In the summer survey, the mean surface density was 0.046 turtles $\mathrm{km}^{-2}$, with a total surface estimate of 4083 animals in the whole study area $(\mathrm{CV}=$ $14.59 \%$; $95 \%$ CI = 3061 to 5446) (Table 3). Sub-region $\mathrm{C}$ presented higher surface density values (by $\sim 2.5$ times) and thus abundance (by $\sim 3$ to 4 times) than subregions A or B (Table 2).

The power analysis results indicate that with $80 \%$ power, the time to detect a $2 \%$ range of annual declines is $18 \mathrm{yr}, 10 \mathrm{yr}$ for $5 \%, 7$ yr for $10 \%$ and 6 yr for $15 \%$.

\section{DISCUSSION}

This study represents the first investigation of the winter and summer abundance of loggerhead sea turtles in the Ligurian/Corsican and north Tyrrhenian Seas.

\section{Study caveats}

The analyses presented here assume that all sightings were of loggerhead sea turtles. In fact, 2 other sea turtle species occur in the Mediterranean Basin (Groombridge 1990, Casale \& Margaritoulis 2010): the green sea turtle Chelonia mydas and the leatherback sea turtle Dermochelys coriacea. Fortu- 
Table 2. Winter and summer loggerhead sea turtle abundance and density estimates for each study area sub-region (see Fig. 1)

\begin{tabular}{|c|c|c|c|c|c|c|c|c|}
\hline Sub-region & $\begin{array}{c}\text { Transect } \\
\text { length }(\mathrm{km})\end{array}$ & $\begin{array}{c}\text { No. } \\
\text { transects }\end{array}$ & $\begin{array}{c}\text { No. } \\
\text { sightings }\end{array}$ & $\begin{array}{l}\text { Density } \\
\text { estimate }\end{array}$ & $\begin{array}{c}\text { Abundance } \\
\text { estimate }\end{array}$ & $\begin{array}{l}\mathrm{CV} \\
(\%)\end{array}$ & $\begin{array}{c}\text { Lower } \\
95 \% \text { CL }\end{array}$ & $\begin{array}{c}\text { Upper } \\
95 \% \text { CL }\end{array}$ \\
\hline \multicolumn{9}{|l|}{ Winter } \\
\hline A & 3167.9 & 38 & 3 & 0.00234 & 72 & 57.18 & 24 & 222 \\
\hline B & 2038.2 & 16 & 3 & 0.00364 & 85 & 77.64 & 17 & 411 \\
\hline $\mathrm{C}$ & 2938.3 & 22 & 3 & 0.00252 & 86 & 34.31 & 42 & 179 \\
\hline Total & 8144.4 & 76 & 9 & 0.0026 & 237 & 34.33 & 122 & 461 \\
\hline \multicolumn{9}{|l|}{ Summer } \\
\hline A & 3033.3 & 34 & 39 & 0.031 & 968 & 24.51 & 0.018 & 0.052 \\
\hline B & 2264.8 & 20 & 23 & 0.024 & 574 & 36.01 & 265 & 1246 \\
\hline $\mathrm{C}$ & 3148.8 & 25 & 93 & 0.071 & 2458 & 19.31 & 1634 & 3698 \\
\hline Total & 8446.9 & 79 & 155 & 0.046 & 4083 & 14.59 & 3061 & 5446 \\
\hline
\end{tabular}

Table 3. Estimates of sea turtle bycatch in the Mediterranean Sea

\begin{tabular}{|llll|}
\hline Fishing gear & Area & Catch rate & Source \\
\hline Long line & Pelagos Sanctuary & 0.00062 turtles 1000 hooks $^{-1}$ & Orsi Relini et al. (1999) \\
& Spanish waters & $0.1-4.48$ turtles 1000 hooks $^{-1}$ & Báez et al. (2007) \\
& Sicily channel & 0.977 turtles 1000 hooks & Casale et al. (2007c) \\
& Ionian Sea & $0.128-0.446$ turtles 1000 hooks & \\
Driftnet & Ligurian Sea & 0.05 turtles d & Deflorio et al. (2005) \\
& Spanish waters & 0.968 turtles d & Di Natale et al. (1995) \\
& Ionian Sea & $3-50$ turtles d & \\
& & & Silvani et al. (1999) \\
& & & De Metrio \& Megalofonou (1988) \\
\hline
\end{tabular}

nately, both show distinct morphological and ecological characteristics that render species misidentification unlikely. The leatherback sea turtle has a unique leathery black carapace and only large individuals (>110 cm carapace length) enter the Mediterranean Sea (Casale et al. 2003). Green sea turtles, although potentially more likely to be confused with loggerhead sea turtles given their appearance, almost exclusively frequent the easternmost part of the Mediterranean Sea; only a few have been recorded from the western basin (Casale \& Margaritoulis 2010).

A fundamental assumption of line transect methodology is that all animals on the track line are always detected (Buckland et al. 2001). As noted above, our estimates were not corrected for the 2 main biases that result in a violation of this assumption: availability bias and perception bias. Both of these result (perhaps substantially) in negatively biased abundance estimates. It is possible to correct for availability bias provided that there are reliable data on the proportion of time animals are unavailable to be seen (and the uncertainty around any estimated proportion). To provide an idea of the possible order of magnitude of the underestimate, the closest region to our study area where such information is available is the southwestern Mediterranean Sea. There, in July, loggerhead sea turtles were reported to spend an average of $40 \%$ of time at the surface (Revelles et al. 2007). A full analysis (including appropriate estimates of uncertainty) would require an examination of the raw data, but if we assume that this result was also representative of the animals in our study area, a corrected point estimate of abundance would have been approximately 600 and 10000 turtles in the Pelagos Sanctuary in winter and summer 2009, respectively. Perception bias, in contrast, is usually corrected for by an independent observer approach, i.e. some or all of the surveys are undertaken with more than one observer independently searching the same area and recording data separately, known as the 'double platform' approach (see Buckland et al. 2001). However, the size of our aircraft precluded the additional persons needed to apply this approach in the present survey.

Another source of perception bias for sea turtles is the difficulty or impossibility of detecting very small specimens such as hatchlings, which are approximately $4.5 \mathrm{~cm}$ (straight-line carapace length, Dodd 1988 ) and which can frequent open waters. However, 
the known nesting sites are far from the study area and Casale et al. (2010) reported the mean $( \pm$ SD) curved carapace length (CCL) of loggerhead sea turtles found along the north Tyrrhenian coast to be $47.6 \pm 11.8 \mathrm{~cm}(\mathrm{n}=175)$, with a minimum $\mathrm{CCL}$ of $25 \mathrm{~cm}$. Nevertheless, when flying at an altitude of $750 \mathrm{ft}$ (ca. $230 \mathrm{~m}$ ), we are likely to have missed some smaller specimens.

\section{Large-scale abundance patterns}

The present estimate of sea turtle abundance in the Pelagos Sanctuary contributes to a better picture of the relative importance of different Mediterranean areas as foraging grounds for sea turtles. However, to advance this understanding, aerial surveys in other areas are required (Panigada et al. 2011). Although some estimates have been provided in various areas on the number of adult females (e.g. Broderick et al. 2002), e.g. the annual number of nests in several major nesting beaches (Casale \& Margaritoulis 2010) and some demographic parameters such as sex ratio, survival rates and duration of the juvenile stage (Casale et al. 2006, 2007a, 2009), a comprehensive estimate of population size is not yet available. Moreover, an important gap of information about nesting level is present in Libya (Casale \& Margaritoulis 2010). All of the above considerations prevent a meaningful comparison of our results, which concern sea turtles in all size classes, i.e. both adults and juveniles, the latter representing the majority of the population.

\section{Evidence for migration}

Absolute abundance estimates are important for assessing the importance of anthropogenic mortality at the population level. However, trends can also be examined using relative abundance, if data collection methods are comparable. Accounting for biases when examining trends in relative abundance is much less important if they can be assumed to be consistent across surveys (e.g. Donovan 2005). Such an assumption is clearly true for the present surveys. Indeed, the very low numbers of sightings (and hence density and abundance in the area) in winter compared with summer clearly represent a true phenomenon, at least for 2009, and indicate seasonal migrations in and out of the study area.
From a physiological perspective, loggerhead sea turtles have been reported as 'active' above 15 to $17^{\circ} \mathrm{C}$ (Laurent \& Lescure 1994) and, to some extent, even at temperatures as low as $12^{\circ} \mathrm{C}$ (Hochscheid et al. 2007). Below $8^{\circ} \mathrm{C}$ they can experience serious problems (Spotila et al. 1997). Low temperatures have been suggested as a factor in seasonal migrations of this species. For example, seasonal (northsouth) migrations have been described for the northwestern Atlantic (Musick \& Limpus 1997), where juvenile and adult female turtles foraging along the coast were found to move to the south when temperature decreased below $20^{\circ} \mathrm{C}$ in winter (Hawkes et al. 2007, Mansfield et al. 2009). However, not all juveniles and females tracked during these studies showed such a seasonal southerly migration, as some specimens frequented other foraging areas in the north. Therefore, north-south seasonal migrations cannot be considered a general pattern for all individuals in a population, nor are observed in all populations (e.g. Limpus \& Limpus 2001).

The evidence for migration in the western Mediterranean Sea is somewhat equivocal. For example, no clear seasonal patterns were suggested from some of the available satellite tracking data (Cardona et al. 2005) or capture-recapture data (Casale et al. $2007 b)$. However, regular seasonal movements of at least adult females have been reported from other telemetry studies (reviewed in Conant et al. 2009). Lazar et al. (2003) provided evidence of seasonal migration from a small area in the northernmost sector of the Adriatic Sea, where temperatures in winter drop below 11 to $12^{\circ} \mathrm{C}$. They recorded high densities in summer and low densities in winter. Gómez de Segura et al. (2006) also inferred seasonal migration for Spanish waters. During our winter study in the Pelagos area, the sea surface temperature was approximately 12 to $13^{\circ} \mathrm{C}$ (Fig. 4) and it may be that this induced most of the turtles to move to warmer (southern) waters. Low temperatures represent the most likely reason for a reduction of the observed low number of turtles at the surface occurring in the area in winter. However, low temperatures can also decrease the time turtles spend at the surface (Bentivegna et al. 2003, Broderick et al. 2007, Hochscheid et al. 2007) and, consequently, the number of turtles observed at the surface during aerial surveys. The sea surface temperature was approximately 12 to $13^{\circ} \mathrm{C}$ in winter and 23 to $25^{\circ} \mathrm{C}$ in summer (Fig. 4) (www.seaturtle.org).

In summary, our data show that loggerhead turtles were scarce in the northern part of the western Mediterranean Sea during January and February 

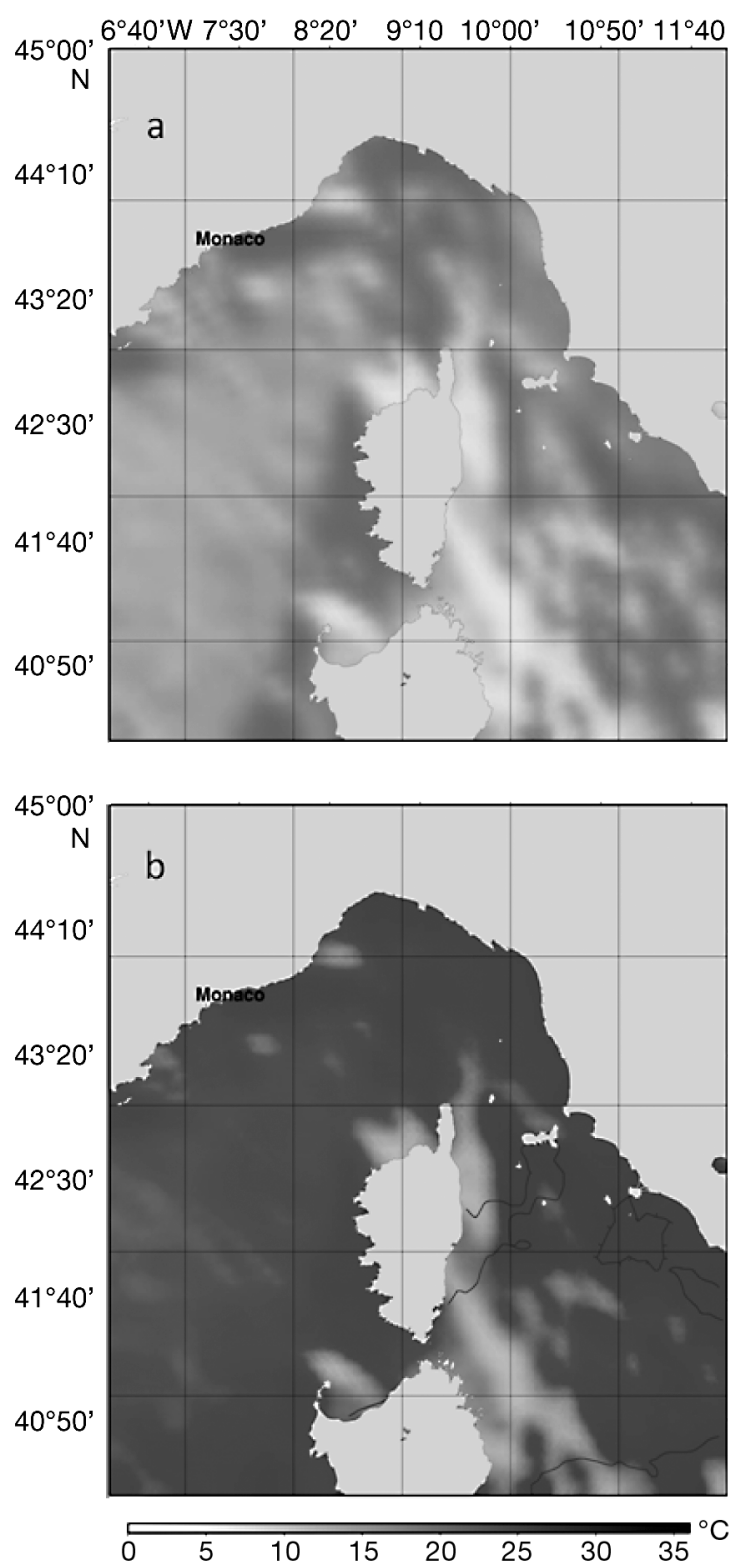

Fig. 4. Sea surface temperature $\left(\mathrm{SST}_{;}{ }^{\circ} \mathrm{C}\right)$ in the study area in (a) winter and (b) summer

2009 (the time of the winter survey), probably due to low temperatures (Fig. 4a). By contrast, they frequented the area in considerable numbers during summer.

\section{Factors affecting habitat use}

Within our study area during summer, there was a clear difference in density between the highestdensity sub-region $\mathrm{C}$ and the other 2 sub-regions. In terms of temperature (Fig. 4b), all sub-regions were well above the threshold for activity indicated by Laurent \& Lescure's (1994) study; sub-region C presented the lowest temperature between the 3 subregions $\left(23^{\circ} \mathrm{C}\right)$. It is not surprising that above a certain value, absolute temperature alone does not explain sea turtle density and distribution. Depth is known to affect sea turtle distribution, because in shallow waters sea turtles have access to benthic prey. However, all 3 sub-regions have seafloor depths that are comparable and in most of the subregions depth is well beyond the diving capacity of loggerhead sea turtles (Fig. 1) (Lutcavage \& Lutz 1997). Moreover, most sea turtles were observed in deep water (Fig. 3), thus a direct effect of depth on distribution seems unlikely. It seems much more probable that sea turtle distribution is related to prey density and accessibility or even to a passive concentration by currents (Hawkes et al. 2007, Revelles et al. 2007, Mansfield et al. 2009, Mencacci et al. 2010). Other studies have shown that sea turtles tend to concentrate in water fronts with sharp temperature and chlorophyll gradients, where a convergence of phytoplankton and zooplankton occurs, the latter representing a trophic resource for turtles (Polovina et al. 2000, Kobayashi et al. 2008, Mansfield et al. 2009). Sub-region $C$ in our study area is known to be an important area for phytoplankton blooms (D'Ortenzio \& Ribera d'Alcala 2008).

The only other area of the Mediterranean Sea with a data set similar to that of the present study is the Spanish Mediterranean waters covered by Gómez de Segura et al. (2006). Although direct comparisons of the abundance and density estimates between the Spanish study and the present study are not appropriate, particularly because of differences in study area size, the time elapsed between the surveys and possible natural variation in distribution and abundance amongst years, the results suggest that there may be significantly lower densities of sea turtles during the summer in the Pelagos Sanctuary (overall $0.046 \mathrm{~km}^{-2}$, Sub-region C $\left.0.071 \mathrm{~km}^{-2}\right)$ than in Spanish waters $\left(0.21 \mathrm{~km}^{-2}\right.$; Gómez de Segura et al. 2006).

With similar provisos about survey and/or study timing, and notwithstanding the uncertainties surrounding bycatch data, a similar inference can be drawn from the estimated bycatch rates (both for pelagic longliners and driftnets) for the Pelagos Sanctuary compared with Spanish waters and the Ionian Sea (Table 3), if it is assumed that, in general, higher bycatch rates equate to higher sea turtle abundance. 
The reasons for this difference in densities remain unclear. Temperature is an unlikely explanation, as the temperatures in the 2 areas are similar (23 to $25^{\circ} \mathrm{C}$ in July 2009 in the Pelagos Sanctuary and 25 to $26^{\circ} \mathrm{C}$ in the Spanish Mediterranean waters). Hence, other factors related to prey and/or currents seem more likely to influence sea turtle occurrence (Bentivegna et al. 2007). In addition, as reported by Carreras et al. (2006), the waters of southern Spain are frequented by high numbers of Atlantic loggerhead sea turtles, whereas the northern coast of Spain and the Tyrrhenian Sea are frequented mostly by sea turtles of Mediterranean origin, which probably distribute also along the Liguro-Provençal current.

\section{Conservation implications}

Pertinent to the data and discussion that we have presented, to assess population-level effects and monitor the success of mitigation measures, both population structure and movements, in addition to abundance must be understood. Genetic and telemetry studies are required to investigate whether the animals surveyed within an area, including those bycaught or vessel struck, belong to the Mediterranean RMU or incorporate animals from the northwest Atlantic RMU (Wallace et al. 2010), as well as to verify the appropriateness of those RMUs. In this context, the Pelagos Sanctuary appears to include only Mediterranean animals.

The presence of sea turtles in the Pelagos Sanctuary during summer exposes them to high levels of maritime traffic, including fishing, pleasure and recreational boats, leading to death from bycatch and boat collisions (Panigada et al. 2008, Casale et al. 2010). The effects of intense human activities must be evaluated at the population level and, if necessary, targeted mitigation measures for sea turtles should be considered within the Pelagos Sanctuary.

The present study shows that a well-designed longterm aerial survey programme can form part of an efficient and effective strategy to monitor species of conservation concern. These long-term monitoring programmes should be planned according to the power analysis results, which can also help to calculate the number of replicates needed to detect biologically significant abundance declines. Long-term monitoring programmes represent the only way to understand population status, evaluate the effect of human-induced mortality and provide an index of the effectiveness of suggested and applied conservation measures and mitigation policies (e.g. Donovan 2005).
Acknowledgements. Both surveys were carried out thanks to funds provided by the Italian Ministry of the Environment. We are grateful to T. Agardy for her input on the paper. A special thank you goes to C. Plaisance and M. Albertario, the pilots of the Partenavia P68, as well as to all the people who helped us with the logistics. We also thank L. Burt from CREEM (St. Andrews University, Scotland) for advice on data analyses, and the anonymous reviewers for the useful comments. D. Ainley (Senior Ecological Associate, H. T. Harvey and Associates, Los Gatos, CA, USA) provided useful comments on a final version.

\section{LITERATURE CITED}

Akaike H (1974) A new look at the statistical model identification. System identification and time-series analysis. IEEE Trans Automat Contr 19:716-723

Arnau P, Liquete C, Canals M (2004) River mouth plume events and their dispersal in the Northwestern Mediterranean Sea. Oceanography 17:23-31

> Báez JC, Real R, García-Soto C, de la Serna JM, Macías D, Camiñas JA (2007) Loggerhead turtle by-catch depends on distance to the coast, independent of fishing effort: implications for conservation and fisheries management. Mar Ecol Prog Ser 338:249-256

Bentivegna F, Hochscheid S, Minucci C (2003) Seasonal variability in voluntary dive duration of the Mediterranean loggerhead turtle, Caretta caretta. Sci Mar 67: 371-375

Bentivegna F, Valentino F, Falco P, Zambianchi E, Hochscheid $S$ (2007) The relationship between loggerhead turtle (Caretta caretta) movement patterns and Mediterranean currents. Mar Biol 151:1605-1614

Bjorndal KA (1997) Foraging ecology and nutrition of sea turtles. In: Lutz PL, Musick JA (eds) The biology of sea turtles. CRC Marine Science Series, CRC Press, Boca Raton, FL, p 199-232

Bolten AB (2003) Active swimmers - passive drifters: the oceanic juvenile stage of loggerheads in the Atlantic system. In: Bolten $\mathrm{AB}$, Witherington $\mathrm{BE}$ (eds) Loggerhead sea turtles. Smithsonian Books, Washington, DC, p 63-78

- Bolten AB, Bjorndal KA, Martins HR, Dellinger T, Biscoito MJ, Encalada SE, Bowen BW (1998) Transatlantic developmental migrations of loggerhead sea turtles demonstrated by mtDNA sequence analysis. Ecol Appl 8:1-7

Bowen BW, Abreugrobois FA, Balazs GH, Kamezaki N, Limpus CJ, Ferl RJ (1995) Trans-Pacific migrations of the loggerhead turtle (Caretta caretta) demonstrated with mitochondrial-DNA markers. Proc Natl Acad Sci USA 92: 3731-3734

Braun J, Epperly SP (1996) Aerial surveys for sea turtles in the southern Georgia waters, June, 1991. Gulf Mex Sci 14:39-44

Braun-McNeill J, Sasso CR, Epperly SP, Rivero C (2008) Feasibility of using sea surface temperature imagery to mitigate cheloniid sea turtle-fishery interactions off the coast of northeastern USA. Endang Species Res 5: 257-266

Broderick AC, Glen F, Godley BJ, Hays GC (2002) Estimating the number of green and loggerhead turtles nesting annually in the Mediterranean. Oryx 36:227-235

Broderick AC, Coyne MS, Fuller WJ, Glen F, Godley BJ (2007) Fidelity and over-wintering of sea turtles. Proc R Soc Lond B 274:1533-1538 
Buckland ST, Anderson DR, Burnham KP, Laake JL, Borchers DL, Thomas L (2001) Introduction to distance sampling: estimating abundance of biological populations. Oxford University Press, Oxford

> Cardona L, Revelles M, Carreras C, San Félix M, Gazo M, Aguilar A (2005) Western Mediterranean immature loggerhead turtles: habitat use in spring and summer assessed through satellite tracking and aerial surveys. Mar Biol 147:583-591

> Carreras C, Pont S, Maffucci F, Pascual M and others (2006) Genetic structuring of immature loggerhead sea turtles (Caretta caretta) in the Mediterranean Sea reflects water circulation patterns. Mar Biol 149:1269-1279

Casale P (2011) Sea turtle by-catch in the Mediterranean. Fish Fish 12:299-316

Casale P, Margaritoulis D (eds) (2010) Sea turtles in the Mediterranean: distribution, threats and conservation priorities. IUCN/SSC Marine Turtle Specialist Group, Gland

Casale P, Nicolosi P, Freggi D, Turchetto M, Argano R (2003) Leatherback turtles (Dermochelys coriacea) in Italy and in the Mediterranean basin. Herpetol J 13:135-139

> Casale P, Lazar B, Pont S, Tomás J and others (2006) Sex ratios of juvenile loggerhead sea turtles Caretta caretta in the Mediterranean Sea. Mar Ecol Prog Ser 324: 281-285

> Casale P, Mazaris AD, Freggi D, Basso R, Argano R (2007a) Survival probabilities of loggerhead sea turtles (Caretta caretta) estimated from capture-mark-recapture data in the Mediterranean Sea. Sci Mar 71:365-372

Casale P, Freggi D, Basso R, Vallini C, Argano R (2007b) A model of area fidelity, nomadism, and distribution patterns of loggerhead sea turtles (Caretta caretta) in the Mediterranean Sea. Mar Biol 152:1039-1049

Casale P, Cattarino L, Freggi D, Rocco M, Argano R (2007c) Incidental catch of marine turtles by Italian trawlers and longliners in the central Mediterranean. Aquat Conserv: Mar Freshw Ecosyst 17:686-701

Casale P, Abbate G, Freggi D, Conte N, Oliverio M, Argano R (2008a) Foraging ecology of loggerhead sea turtles Caretta caretta in the central Mediterranean Sea: evidence for a relaxed life history model. Mar Ecol Prog Ser 372:265-276

Casale P, Freggi D, Gratton P, Argano R, Oliverio M (2008b) Mitochondrial DNA reveals regional and interregional importance of the central Mediterranean African shelf for loggerhead sea turtles (Caretta caretta). Sci Mar 72: 541-548

Casale P, Mazaris A, Freggi D, Vallini C, Argano R (2009) Growth rates and age at adult size of loggerhead sea turtles (Caretta caretta) in the Mediterranean Sea, estimated through capture-mark-recapture records. Sci Mar 73:589-595

Casale P, Affronte M, Insacco G, Freggi D and others (2010) Sea turtle strandings reveal high anthropogenic mortality in Italian waters. Aquat Conserv 20:611-620

Conant TA, Dutton PH, Eguchi T, Epperly SP and others (2009) Loggerhead sea turtle (Caretta caretta) 2009 status review under the US Endangered Species Act. Report of the Loggerhead Biological Review Team to the National Marine Fisheries Service, available at www. seaturtle.org/PDF/ConantTA_2009_NMFSTechReport. pdf.

D'Ortenzio F, Ribera d'Alcala M (2008) On the trophic regimes of the Mediterranean Sea: a satellite analysis.
Biogeosci Discuss 5:2959-2983

Davis RW, Fargion GS (eds) (1996) Distribution and abundance of cetaceans in the north-central and western Gulf of Mexico: Final report, Vol. II: Technical Report. OCS Study MMS 96-0027. Prepared by the Texas Institute of Oceanography and the National Marine Fisheries Service, New Orleans, LA

Davis RW, Evans WE, Würsig B (eds) (2000) Cetaceans, sea turtle and seabirds in the northern Gulf of Mexico: distribution, abundance and habitat associations, Vol. II: Technical Report. OCS Study MMS 2000-003. Prepared by Texas A\&M University at Galveston and the National Marine Fisheries Service, New Orleans, LA

De Metrio G, Megalofonou P. (1988) Mortality of marine turtles (Caretta caretta L. and Dermochelys coriacea L.) consequent to accidental capture in the Gulf of Taranto. Rapp Comm Int Mer Médit 31:285

> Deflorio M, Aprea A, Corriero A, Santamaria N, De Metrio G (2005) Incidental captures of sea turtles by swordfish and albacore longlines in the Ionian sea. Fish Sci 71: 1010-1018

Di Natale A, Mangano A, Maurizi L, Montaldo E and others (1995) A review of driftnet catches by the italian fleet: species composition, observer data and distribution along the net. Collect Vol Sci Pap ICCAT 44:226-235

Dodd CKJ (1988) Synopsis of the biological data on the loggerhead sea turtle Caretta caretta (Linnaeus 1758). US Fish Wildl Serv Biol Rep 88:1-119

Donovan G (2005) Cetaceans: Can we manage to conserve them? The role of long-term monitoring. In: Solbé J (ed) Long-term monitoring: Why, what, where, when and how? Sherkin Island Marine Station, Sherkin Island, Cork, p 161-174

Eguchi T, Gerrodette T, Pitman RL, Seminoff JA, Dutton PH (2007) At-sea density and abundance estimates of the olive ridley turtle Lepidochelys olivacea in the eastern tropical Pacific. Endang Species Res 3:191-203

Epperly SP, Braun J, Chester AJ (1995) Aerial surveys for sea turtles in North Carolina inshore waters. Fish Bull 93: $254-261$

Estrada M (1996) Primary production in the northwestern Mediterranean. Sci Mar 60:55-64

> Fewster RM, Buckland ST, Burnham KP, Borchers DL, Jupp PE, Laake JL, Thomas L (2009) Estimating the encounter rate variance in distance sampling. Biometrics 65: $225-236$

> Forcada J, Notarbatolo di Sciara GN, Fabbri F (1995) Abundance of fin whales and striped dolphins summering in the Corso-Ligurian Basin. Mammalia 59:127-140

Frick MG, Williams KL, Bolten AB, Bjorndal KA, Martins HR (2009) Foraging ecology of oceanic-stage loggerhead turtles Caretta caretta. Endang Species Res 9:91-97

Gerrodette T (1993) TRENDS: software for a power analysis of linear regression. Wildl Soc Bull 21:515-516

> Gómez de Segura A, Tomas J, Pedraza SN, Crespo EA, Raga JA (2003) Preliminary patterns of distribution and abundance of loggerhead sea turtles, Caretta caretta, around Columbretes Islands Marine Reserve, Spanish Mediterranean. Mar Biol 143:817-823

- Gómez de Segura A, Tomas J, Pedraza SN, Crespo EA, Raga JA (2006) Abundance and distribution of the endangered loggerhead turtle in Spanish Mediterranean waters and the conservation implications. Anim Conserv 9:199-206

Groombridge B (1990) Marine turtles in the Mediterranean: distribution, population status, conservation. Nature and 
Environment Series No. 48, Council of Europe, Strasbourg

> Hamann M, Godfrey MH, Seminoff JA, Arthur K and others (2010) Global research priorities for sea turtles: informing management and conservation in the 21st century. Endang Species Res 11:245-269

> Hawkes LA, Broderick AC, Coyne MS, Godfrey MH and others (2006) Phenotypically linked dichotomy in sea turtle foraging requires multiple conservation approaches. Curr Biol 16:990-995

Hawkes LA, Broderick AC, Coyne MS, Godfrey MH, Godley BJ (2007) Only some like it hot-quantifying the environmental niche of the loggerhead sea turtle. Divers Distrib 13:447-457

Hawkes LA, Broderick AC, Godfrey MH, Godley BJ (2009) Climate change and marine turtles. Endang Species Res 7:137-154

> Hazel J, Lawler IR, Marsh H, Robson S (2007) Vessel speed increases collision risks for the green turtle Chelonia mydas. Endang Species Res 3:105-113

Hochscheid S, Bentivegna F, Bradai MN, Hays GC (2007) Overwintering behaviour in sea turtles: dormancy is optional. Mar Ecol Prog Ser 340:287-298

Howell EA, Kobayashi DR, Parker DM, Balazs GH, Polovina JJ (2008) TurtleWatch: a tool to aid in the bycatch reduction of loggerhead turtles Caretta caretta in the Hawaiibased pelagic longline fishery. Endang Species Res 5: $267-278$

Hoyt E (2005) Marine protected areas for whales, dolphins and porpoises: a world handbook for cetacean habitat conservation. Earthscan Publications, London

Kobayashi DR, Polovina JJ, Parker DM, Kamezaki N and others (2008) Pelagic habitat characterization of loggerhead sea turtles, Caretta caretta, in the North Pacific Ocean (1997-2006): insights from satellite tag tracking and remotely sensed data. J Exp Mar Biol Ecol 356: 96-114

Laurent L, Lescure J (1994) L'hivernage des tortues caouannes Caretta caretta (L.) dans le sud de Tunisie. Rev Ecol Terre Vie 49:63-86

- Laurent L, Casale P, Bradai MN, Godley BJ and others (1998) Molecular resolution of marine turtle stock composition in fishery bycatch: a case study in the Mediterranean. Mol Ecol 7:1529-1542

Lauriano G, Panigada S (2010) Aerial survey in the Pelagos Sanctuary for the management and conservation of the protected species. Biol Mar Medit 17:43-46

Lazar B, Borboroglu PG, Tvrtkovic N, Ziza V (2003) Temporal and spatial distribution of the loggerhead sea turtle, Caretta caretta, in the eastern Adriatic Sea: A seasonal migration pathway? In: Seminoff JA (ed) Twenty-second Annual Symposium on Sea Turtle Biology and Conservation. NOAA Tech Memo NMFS-SEFSC-503, Miami, FL, p 283-284

Limpus CJ, Limpus DJ (2001) The loggerhead turtle, Caretta caretta, in Queensland: breeding migrations and fidelity to a warm temperate feeding area. Chelonian Conserv Biol 4:142-153

Lutcavage ME, Lutz PL (1997) Diving physiology. In: Lutz PL, Musick JA (eds) The biology of sea turtles. CRC Marine Science Series, CRC Press, Boca Raton, FL, p 277-296

Mansfield KL, Saba VS, Keinath JA, Musick JA (2009) Satellite tracking reveals a dichotomy in migration strategies among juvenile loggerhead turtles in the Northwest
Atlantic. Mar Biol 156:2555-2570

Margaritoulis D, Argano R, Baran I, Bentivegna F and others (2003) Loggerhead turtles in the Mediterranean Sea: present knowledge and conservation perspectives. In: Bolten $A B$, Witherington $B$ (eds) Biology and conservation of loggerhead sea turtles. Smithsonian Institution Press, Washington, DC, p 175-198

Marques TA, Thomas L, Fancy SG, Buckland ST (2007) Improving estimates of bird density using multiple covariate sampling. Auk 124:1229-1243

McClellan CM, Read AJ (2007) Complexity and variation in loggerhead sea turtle life history. Biol Lett 3:592-594

> Mencacci R, De Bernardi E, Sale A, Lutjeharms JRE, Luschi $P$ (2010) Influence of oceanic factors on long-distance movements of loggerhead sea turtles displaced in the southwest Indian Ocean. Mar Biol 157:339-349

Musick JA, Limpus CJ (1997) Habitat utilization and migration in juvenile sea turtles. In: Lutz PL, Musick JA (eds) The biology of sea turtles. CRC Marine Science Series, CRC Press, Boca Raton, FL, p 137-163

Notarbatolo di Sciara GN, Venturino MC, Zanardelli M, Bearzi G, Borsani JF, Cavalloni B (1993) Cetaceans in the central Mediterranean Sea: distribution and sighting frequencies. Ital J Zool 60:131-138

Notarbatolo di Sciara GN, Agardy T, Hyrenbach D, Scovazzi T, Van Klaveren P (2008) The Pelagos Sanctuary for Mediterranean marine mammals. Aquat Conserv 18: 367-391

Orsi Relini L, Palandri G, Garibaldi F, Cima C (1999) Longline swordfish fishery in the Ligurian Sea: eight years of observation on target and bycatch species. Collect Vol Sci Pap ICCAT 49:146-150

Panigada S, Pavan G, Borg JA, Galil BS, Vallini C (2008) Biodiversity impacts of ship movement, noise, grounding and anchoring. In: Abdulla A, Linden O (eds) Maritime traffic effects on biodiversity in the Mediterranean Sea: review of impacts, priority areas and mitigation measures. IUCN Centre for Mediterranean Cooperation, Malaga, p 10-21

Panigada S, Lauriano G, Burt L, Pierantonio N, Donovan G (2011) Monitoring winter and summer abundance of cetaceans in the pelagos sanctuary (Northwestern Mediterranean Sea) through aerial surveys. PLoS ONE 6(7):e22878

Polovina JJ, Kobayashi DR, Parker DM, Seki MP, Balazs GH (2000) Turtles on the edge: movement of loggerhead turtles (Caretta caretta) along oceanic fronts, spanning longline fishing grounds in the central North Pacific, 1997-1998. Fish Oceanogr 9:71-82

> Preen AR, Marsh H, Lawler IR, Prince RIT, Shepherd R (1997) Distribution and abundance of dugong, turtles, dolphins and other megafauna in Shark Bay, Ningaloo reef and Exmouth Gulf, Western Australia. Wildl Res 24: 185-208

Reich KJ, Bjorndal KA, Frick MG, Witherington BE, Johnson C, Bolten AB (2010) Polymodal foraging in adult female loggerheads (Caretta caretta). Mar Biol 157:113-121

> Revelles M, Cardona L, Aguilar A, San Felix M, Fernandez G (2007) Habitat use by immature loggerhead sea turtles in the Algerian Basin (western Mediterranean): swimming behaviour, seasonality and dispersal pattern. Mar Biol 151:1501-1515

Salat J (1996) Review of hydrographic environmental factors that may influence anchovy habitats in the northwestern Mediterranean. Sci Mar 60:21-32 
Shoop CR, Kenney RD (1992) Seasonal distribution and abundances of loggerhead and leatherback sea turtles in waters of the northeastern United States. Herpetol Monogr 6:43-67

Silvani L, Gazo M, Aguilar A (1999) Spanish driftnet fishing and incidental catches in the western Mediterranean. Biol Conserv 90:79-85

Spotila JR, O'Connor MP, Paladino FV (1997) Thermal biology. In: Lutz PL Musick JA (eds) The biology of sea turtles. CRC Marine Science Series, CRC Press, Boca Raton, FL, p 297-314

Thomas L, Williams R, Sandilands D (2007) Designing line transect surveys for complex survey regions. J Cetacean Res Manag 9:1-13

Thomas L, Laake JL, Rexstad E, Strindberg S and others (2009) Distance 6.0. Release '2'. Research Unit for Wildlife Population Assessment, University of St. Andrews, available at www.ruwpa.st-and.ac.uk/distance/

Thomas L, Buckland ST, Rexstad EA, Laake JL and others (2010) Distance software: design and analysis of distance sampling surveys for estimating population size. J Appl

Editorial responsibility: Hans Heinrich Janssen, Oldendorf/Luhe, Germany
Ecol 47:5-14

Tomás J, Gozalbes P, Raga JA, Godley BJ (2008) Bycatch of loggerhead sea turtles: insights from 14 years of stranding data. Endang Species Res 5:161-169

Wallace BP, DiMatteo AD, Hurley BJ, Finkbeiner EM and others (2010) Regional management units for marine turtles: a novel framework for prioritizing conservation and research across multiple scales. PLoS ONE 5:e15465

Witt MJ, Baert B, Broderick AC, Formia A and others (2009) Aerial surveying of the world's largest leatherback turtle rookery: a more effective methodology for large-scale monitoring. Biol Conserv 142:1719-1727

Witt MJ, Hawkes LA, Godfrey MH, Godley BJ, Broderick AC (2010) Predicting the impacts of climate change on a globally distributed species: the case of the loggerhead turtle. J Exp Biol 213:901-911

Zbinden JA, Aebischer A, Margaritoulis D, Arlettaz R (2008) Important areas at sea for adult loggerhead sea turtles in the Mediterranean Sea: satellite tracking corroborates findings from potentially biased sources. Mar Biol 153: 899-906

Submitted: August 30, 2010; Accepted: June 15, 2011 Proofs received from author(s): September 2, 2011 